INOBIS: Jurnal Inovasi Bisnis dan Manajemen Indonesia

Volume 1, Nomor 2, Maret 2018

Tegowati; Nenny Syahrenny; Wininatin Khamimah; Mega Arisia Dewi

\title{
Strategi Meningkatkan Prestasi Kerja Guru Berdasarkan Motivasi, Kompensasi, Stres Kerja, dan Kepemimpinan
}

\author{
Tegowati, Nenny Syahrenny, Wininatin Khamimah dan Mega Arisia Dewi \\ Sekolah Tinggi Ilmu Ekonomi Indonesia (STIESIA) Surabaya \\ Email: tegowati@stiesia.ac.id
}

\begin{abstract}
Abstrak
Penelitian ini bertujuan untuk menganalisis strategi meningkatkan prestasi kerja guru berdasarkan motivasi, kompensasi, stres kerja dengan moderasi kepemimpinan. Sampel berjumlah 101 responden dengan teknik samplingnya purposive sampling. Berdasarkan analisis data yang dilakukan menggunakan IBM SPSS 20, di peroleh kesimpulan sebagai berikut: 1) Kompensasi berpengaruh positif dan signifikan terhadap prestasi kerja. Hal ini ditunjukkan dari nilai Unstandardized Coefficients sebesar 4.690 dengan signifikansi 0.000. 2) Motivasi kerja berpengaruh positif dan signifikan terhadap prestasi kerja. Hal ini ditunjukkan dari uji t pada nilai Unstandardized Coefficients sebesar 5.073 dengan signifikansi 0.000. 3) Stres kerja tidak berpengaruh terhadap prestasi kerja guru. Hal ini ditunjukkan oleh uji t pada nilai Unstandardized Coefficients sebesar 1.573 dengan signifikansi 0.118. 4) Kompensasi berpengaruh terhadap prestasi kerja guru yang dimoderasi oleh kepemimpinan. Hal ini ditunjukkan oleh nilai Unstandardized Coefficients sebesar 2.072 (negatif) dan signifikansi 0.005 (lebih kecil dari 0.05). 5) Motivasi berpengaruh terhadap prestasi kerja guru yang dimoderasi oleh kepemimpinan. Hal ini ditunjukkan oleh uji t yaitu nilai -1.394 (negatif) dengan signifikansi 0.05 (signifikan pada nilai 0.05). 6) Stres kerja berpengaruh terhadap prestasi kerja guru yang dimoderasi oleh kepemimpinan. Hal ini ditunjukkan oleh nilai Unstandardized Coefficients sebesar -3.097 (negatif) dengan signifikansi 0.000 (lebih kecil dari 0.05).
\end{abstract}

Kata Kunci: Prestasi Kerja, Motivasi, Kompensasi, Stres Kerja, Kepemimpinan.

\section{Pendahuluan}

\subsection{Latar Belakang Penelitian}

Setiap profesi memiliki tekanan yang berbeda sesuai dengan karakteristik pekerjaan dan lingkungan yang dihadapi, yang pada akhirnya menciptakan tingkat stres kerja tersendiri. Sebagaimana seorang guru yang memiliki tanggung jawab dalam mencerdaskan dan mendidik generasi muda bangsa melalui proses belajar mengajar, juga mempunyai stres kerja. Jika stres kerja guru terlalu tinggi maka tidak baik bagi perkembangan anak didiknya, sebab proses belajar mengajar tidak bisa berjalan dengan efektif dan anak didik merasa trauma terhadap ucapan atau tindakan negatif yang mungkin saja dilakukan ketika guru mengalami stres kerja.

Proses belajar mengajar tidak sesederhana seperti yang terlihat pada saat guru menyampaikan materi pelajaran di kelas, tetapi dalam melaksanakan pembelajaran yang baik, seorang guru harus mengadakan persiapan yang baik agar pada saat melaksanakan pembelajaran dapat terarah sesuai dengan tujuan pembelajaran yang terdapat pada indikator keberhasilan pembelajaran. Proses pembelajaran adalah rangkaian kegiatan yang dilakukan oleh seorang guru mulai dari persiapan pembelajaran, pelaksanaan pembelajaran sampai 
INOBIS: Jurnal Inovasi Bisnis dan Manajemen Indonesia

Volume 1, Nomor 2, Maret 2018

Tegowati; Nenny Syahrenny; Wininatin Khamimah; Mega Arisia Dewi

evaluasi dan perbaikan untuk siswa yang belum berhasil pada saat dilakukan evaluasi pembelajaran.

"Tugas pokok guru yang diwujudkan dalam kegiatan belajar mengajar merupakan bentuk kinerja guru. Kinerja sering disebut dengan prestasi yang merupakan hasil atau apa yang keluar (outcomes) dari sebuah pekerjaan dan kontribusi sumber daya manusia terhadap organisasi" (Supardi 2014: 46). Widiartana (2016), menyatakan bahwa motivasi kerja berpengaruh terhadap prestasi kerja. Sedangkan Paulus (2013) menyatakan bahwa kompensasi dan motivasi berpengaruh terhadap prestasi kerja guru, dan Nurmalasari (2015) menyimpulkan stres kerja berpengaruh terhadap prestasi kerja. Berdasarkan penelitianpenelitian terdahulu yang dikemukakan, maka dalam penelitian ini menganalisis prestasi kerja guru berdasarkan motivasi, kompensasi, stres kerja, yang dimoderasi oleh kepemimpinan.

\subsection{Rumusan Penelitian}

1. Bagaimanakah pengaruh kompensasi terhadap prestasi kerja guru?

2. Bagaimanakah pengaruh motivasi terhadap prestasi kerja guru?

3. Bagaimanakah pengaruh stres kerja terhadap prestasi kerja guru?

4. Bagaimanakah pengaruh kompensasi terhadap prestasi kerja guru jika dimoderasi oleh kepemimpinan?

5. Bagaimanakah pengaruh motivasi terhadap prestasi kerja guru jika dimoderasi oleh kepemimpinan?

6. Bagaimanakah pengaruh stres kerja terhadap prestasi kerja guru jika dimoderasi oleh kepemimpinan?

\subsection{Tujuan Penelitian}

1. Menganalisis pengaruh kompensasi terhadap prestasi kerja guru.

2. Menganalisis pengaruh motivasi terhadap prestasi kerja guru.

3. Menganalisis pengaruh stres kerja terhadap prestasi kerja guru.

4. Menganalisis pengaruh kompensasi terhadap prestasi kerja guru jika dimoderasi oleh kepemimpinan.

5. Menganalisis pengaruh motivasi terhadap prestasi kerja guru jika dimoderasi oleh kepemimpinan.

6. Menganalisis pengaruh stres kerja terhadap prestasi kerja guru jika dimoderasi oleh kepemimpinan.

\section{Landasan Teori dan Pengembangan Hipotesis}

\subsection{Prestasi Kerja}

Prestasi kerja merupakan gabungan dari tiga faktor penting, yaitu minat seorang pekerja, kemampuan dan penerimaan atas penjelasan delegasi tugas, serta peran dan tingkat motivasi seorang pekerja. Semakin tinggi ketiga faktor diatas, semakin besarlah prestasi kerja pegawai yang bersangkutan. "Kinerja merupakan suatu kegiatan yang dilakukan untuk melaksanakan, menyelesaikan tugas dan tanggung jawab sesuai dengan harapan dan tujuan yang telah ditetapkan" (Supardi 2014: 45).

Terkait penilaian kinerja guru, Departemen Pendidikan Nasional mempunyai Alat Penilaian Kemampuan Guru (APKG). Alat ini meliputi: (1) rencana pembelajaran (teaching plans and materials) atau disebut dengan RPP (Rencana Pelaksanaan Pembelajaran), (2) 
INOBIS: Jurnal Inovasi Bisnis dan Manajemen Indonesia

Volume 1, Nomor 2, Maret 2018

Tegowati; Nenny Syahrenny; Wininatin Khamimah; Mega Arisia Dewi

prosedur pembelajaran (classroom procedure), dan (3) hubungan antar pribadi (interpersonal skill) (Rachmawati dan Daryanto 2013: 121).

\subsection{Kompensasi}

"Kompensasi merupakan pendapatan berbentuk uang, berbentuk barang langsung atau tidak langsung yang diterima sebagai imbalan atas jasa yang diberikan karyawan kepada perusahaan" (Hasibuan 2002: 118; Paulus 2013). "Pemberian kompensasi dapat juga berbentuk insentif dengan memberikan upah atau gaji yang berbeda karena prestasi kerja yang berbeda, meskipun upah dasarnya sama" (Paulus 2013). Pemberian insentif ini dimaksudkan untuk meningkatkan produktivitas karyawan.

\subsection{Motivasi}

Guru yang memiliki motivasi kerja yang tinggi diharapkan untuk selalu mengembangkan keprofesionalannya dan program inovatif untuk meningkatkan pembelajaran siswa. Teori motivasi menurut Sutrisno (2013: 121) sebagai berikut:

\section{1) Teori Kepuasan}

Teori ini mendasarkan pendekatannya atas faktor-faktor kebutuhan dan kepuasan individu yang menyebabkannya bertindak dan berperilaku dengan cara tertentu. Teori kepuasan antara lain sebagai berikut: Teori Motivasi Konvensional, Teori Hierarki, Teori Motivasi Prestasi, Teori Model dan Faktor, Teori ERG (Existence, Relatedness, Growth) dan Teori X dan Y.

2) Teori Motivasi Proses

Teori-teori proses memusatkan perhatiannya pada bagaimana motivasi terjadi (Sutrisno, 2013:140), dan terdapat tiga teori motivasi proses yang dikenal, yaitu: Teori Harapan (Expectary Theory), Teori Keadilan (Equity Theory) dan Teori Pengukuhan (Reinforcement Theory).

\subsection{Stres Keja}

Menurut Kely et al (2015) "stres kerja adalah suatu kondisi dimana terjadi perubahan psikologis (adanya rasa cemas yang berlebihan, khawatir, dan perasaan tidak nyaman), maupun fisiologis seperti degup jantung meningkat, keringat yang berlebihan, kepala pusing dan gejala fisiologis lainya pada individu disebabkan oleh tekanan yang bersumber dari lingkungan pekerjaan". Menurut Handoko (2001; Suswati dan Ayyubi 2008), "faktor-faktor penyebab stres diantara kondisi-kondisi kerja adalah beban kerja yang berlebih, tekanan atau desakan waktu, kualitas supervisi yang jelek, iklim politis yang tidak aman, umpan balik tentang pelaksanaan kerja yang tidak memadai, wewenang yang tidak mencukupi untuk melaksanakan tanggung jawab, kemenduaan peranan, frustasi, konflik antar pribadi dan antar kelompok, perbedaan nilai-nilai perusahaan dan karyawan, serta berbagai bentuk perubahan". Stres karyawan juga disebabkan masalah yang terjadi diluar perusahaan.

\subsection{Kepemimpinan}

"Kepemimpinan adalah hubungan yang ada dalam diri seorang atau pemimpin, mempengaruhi orang lain untuk bekerja secara sadar dalam hubungan tugas untuk mencapai tujuan yang diinginkan" (Aynul 2008: 177; Zubaidi 2016). Menurut Kartono (2010: 18), 
INOBIS: Jurnal Inovasi Bisnis dan Manajemen Indonesia

Volume 1, Nomor 2, Maret 2018

Tegowati; Nenny Syahrenny; Wininatin Khamimah; Mega Arisia Dewi

"pemimpin adalah seorang pribadi yang memiliki kecakapan dan kelebihan, khususnya kecakapan dan kelebihan di satu bidang sehingga dia mampu mempengaruhi orang lain untuk bersama-sama melakukan aktivitas-aktivitas tertentu demi pencapaian satu atau beberapa tujuan". Seorang pemimpin dapat dipandang efektif apabila dapat membujuk para pengikutnya untuk meninggalkan kepentingan pribadi mereka demi keberhasilan organisasi.

\subsection{Kajian Hubungan Antar Variabel Penelitian}

\section{Hubungan Kompensasi Terhadap Prestasi Kerja}

Kompensasi yang diberikan oleh perusahaan kepada karyawan memiliki pengaruh terhadap prestasi kerja. Jika kompensasi dinilai layak oleh karyawan, maka prestasi kerja karyawan akan baik. Tetapi jika kompensasi yang diberikan lebih kecil daripada beban kerja atau tanggung jawab yang diterima karyawan, maka prestasi kerjanya akan rendah. Hal ini berdasarkan penelitian oleh Paulus (2013), bahwa kompensasi berpengaruh signifikan terhadap prestasi kerja.

\section{Hubungan Motivasi Terhadap Prestasi Kerja}

Pemberian motivasi kerja bagi karyawan akan sangat membantu dalam penyelesaian masalah-masalah yang dihadapi karyawan sehingga akan lebih bersemangat dan percaya diri untuk menyelesaikan pekerjaannya dan dapat mencapai hasil kerja yang maksimal. Meningkatnya motivasi kerja akan meningkatkan prestasi kerja karyawan. Hal ini sesuai dengan penelitian Paulus (2013) dan Widiartana (2016) yang menyatakan bahwa motivasi kerja berpengaruh signifikan terhadap prestasi kerja.

\section{Hubungan Stres Kerja dan Prestasi Kerja}

Stres mempunyai potensi untuk mendorong atau justru menghambat pekerjaan. Stres kerja dalam tingkatan wajar akan menjadi pendorong dalam melaksanakan pekerjaan dan meraih prestasi kerja yang baik. Akan tetapi, bila stres sudah berlebihan, maka stres akan cenderung mengganggu secara psikologis, secara fisik dan menghambat pelaksanaan pekerjaan. Dengan kondisi stres yang tinggi, karyawan akan kehilangan kemampuan untuk mengendalikan stres, tidak mampu untuk mengambil keputusan-keputusan yang baik dan perilakunya menjadi tidak teratur. Akibatnya prestasi kerja semakin menurun. Sebagaimana penelitian yang dilakukan oleh Nurmalasari (2015) bahwa stres kerja berpengaruh signifikan terhadap prestasi kerja.

\section{Hubungan Motivasi Terhadap Prestasi Kerja dengan Moderasi Kepemimpinan}

Dalam melaksanakan pekerjaannya, karyawan yang memiliki motivasi kerja tinggi akan berprestasi lebih baik dibandingkan karyawan yang memiliki motivasi rendah dalam bekerja. Penelitian Hutagalung (2016) menyatakan bahwa kepemimpinan memoderasi pengaruh motivasi terhadap kinerja karyawan. Penelitian tersebut menjelaskan bahwa motivasi kerja karyawan semakin tinggi jika kepemimpinan dalam perusahaan baik dan hal ini berpengaruh terhadap peningkatan prestasi kerja karyawan. akan tetapi meskipun motivasi kerja tinggi, namun prestasi kerjanya akan rendah tanpa adanya dukungan kepemimpinan yang baik. 
INOBIS: Jurnal Inovasi Bisnis dan Manajemen Indonesia

Volume 1, Nomor 2, Maret 2018

Tegowati; Nenny Syahrenny; Wininatin Khamimah; Mega Arisia Dewi

\subsection{Kerangka Konseptual}

Mengacu pada teori dan tujuan penelitian, maka model analisis penelitian ini adalah sebagai berikut:

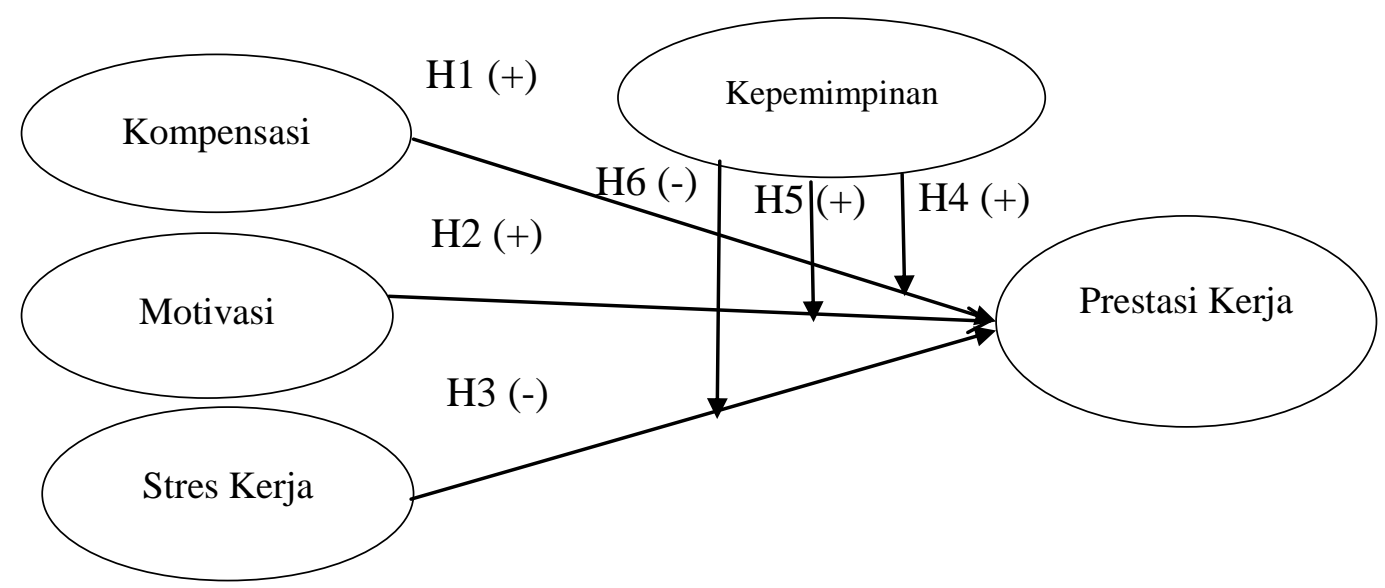

Gambar 1.1: Kerangka Konseptual Hubungan Variabel

\subsection{Hipotesis}

Berdasarkan tujuan penelitian dan model yang diajukan, maka hipotesisnya adalah sebagai berikut:

1. Terdapat pengaruh kompensasi terhadap prestasi kerja guru.

2. Terdapat pengaruh motivasi terhadap prestasi kerja guru.

3. Terdapat pengaruh stres kerja terhadap prestasi kerja guru.

4. Terdapat pengaruh kompensasi terhadap prestasi kerja guru yang dimoderasi oleh kepemimpinan.

5. Terdapat pengaruh motivasi terhadap prestasi kerja guru yang dimoderasi oleh kepemimpinan.

6. Terdapat pengaruh stres kerja terhadap prestasi kerja guru yang dimoderasi oleh kepemimpinan.

\section{Metodologi Penelitian}

\subsection{Jenis Penelitian}

Penelitian ini merupakan penelitian kuantitatif karena dalam penelitian ini data-data disajikan dengan angka-angka dan data-data tersebut dianalisis secara statistik/kuantitatif.

\subsection{Gambaran Populasi}

Populasi dalam penelitian ini adalah seluruh guru SD Swasta di kecamatan Wiyung Surabaya yang berjumlah 161. Sebanyak 161 populasitersebut, ditentukan jumlah sampel berdasarkan metode Krejcie-Morgan. 
INOBIS: Jurnal Inovasi Bisnis dan Manajemen Indonesia

Volume 1, Nomor 2, Maret 2018

Tegowati; Nenny Syahrenny; Wininatin Khamimah; Mega Arisia Dewi

Dicari ukuran sampel untuk populasi 161

\begin{tabular}{cc}
\hline & $S$ \\
\hline 160 & 113
\end{tabular}

$170 \quad 118$

$10 \quad 5$

Interval untuk populasi $=10$

Interval untuk sampel $=5$

Maka perhitungan proporsionalnya adalah:

Untuk N 161 adalah: $113+(5 / 10 * 5)=15,5$ dibulatkan menjadi 116

Dengan demikian, sampel dalam penelitian ini berjumlah 116. Pengumpulan data dilakukan dengan metode nonprobability sampling yaitu teknik purposive sampling.

\subsection{Definisi Operasional Variabel dan Pengukurannya}

\subsubsection{Prestasi Kerja}

Yang dimaksud prestasi kerja dalam penelitian ini adalah hasil kerja baik secara kualitas maupun kuantitas yang dicapai oleh guru dalam melaksanakan tugas sesuai tanggung jawab yang diberikan. Indikator penilaian kinerja guru atau prestasi guru mengacu pada Rachmawati dan Daryanto (2013: 121), yaitu: Perencanaan Program Kegiatan Pembelajaran, Pelaksanaan Kegiatan Pembelajaran dan Evaluasi/Penilaian Pembelajaran.

\subsubsection{Kompensasi}

Yang dimaksud kompensasi dalam penelitian ini adalah semua pendapatan guru yang berbentuk uang, barang langsung atau tidak langsung yang diterima guru sebagai imbalan atas jasa yang diberikan kepada sekolah. Indikator yang digunakan untuk mengukur kompensasi mengacu pada Simamora (2004: 442; Dewi 2014) yaitu: Gaji yang adil sesuai dengan pekerjaan, Insentif yang sesuai dengan pengorbanan, Tunjangan yang sesuai dengan harapan, Fasilitas yang memadai.

\subsubsection{Motivasi}

Yang dimaksud motivasi dalam penelitian ini adalah faktor yang mendorong guru untuk melaksanakan tugas dan tanggung jawabnya dengan baik sesuai dengan tujuan yang telah ditetapkan. Indikator yang digunakan untuk mengukur motivasi mengacu George dan Jones (2005: 175; Wijaya dan Andreani 2015) yaitu: Termotivasi untuk bekerja, Berusaha menyelesaikan pekerjaan dan Tetap bekerja dengan gigih sekalipun ada masalah.

\subsubsection{Stres Kerja}

Yang dimaksud stres kerja dalam penelitian ini adalah kondisi ketegangan yang menciptakan adanya ketidakseimbangan fisik dan psikis, yang mempengaruhi emosi, proses berpikir, dan kondisi guru. Indikator yang digunakan untuk mengukur stres kerja dalam penelitian ini mengacu pada Mas'Ud (2004: 251; Dewi 2014) sebagai berikut: Beban kerja yang berlebihan, Wewenang yang diberikan tidak sesuai dengan tanggung jawab, Konflik dalam organisasi, Perbedaan pendapat dalam pekerjaan dan Masalah keluarga. 


\author{
INOBIS: Jurnal Inovasi Bisnis dan Manajemen Indonesia \\ Volume 1, Nomor 2, Maret 2018 \\ Tegowati; Nenny Syahrenny; Wininatin Khamimah; Mega Arisia Dewi
}

\title{
3.3.5. Kepemimpinan
}

Yang dimaksud kepemimpinan dalam penelitian ini adalah hubungan yang ada dalam diri seorang kepala sekolah dalam mempengaruhi guru untuk bekerja secara sadar dalam melaksanakan tugas untuk mencapai tujuan yang diinginkan. Indikator yang digunakan untuk mengukur kepemimpinan mengacu pada Budiyono (2004: 93; Widiartana 2016) yaitu: Mampu membuat perencanaan, Mampu mengkoordinasi, Mampu menggerakan karyawan, Mampu berkomunikasi dengan karyawan, Mampu mengawasi/mengontrol, Jujur/konsisten dalam memimpin, Tanggung jawab, Hubungan kerja dengan karyawan, Mau menerima keluhan/pendapat karyawan dan Tidak pilih kasih

\subsection{Teknik Analisis Data}

Alat pengukuran data yang digunakan dalam penelitian ini adalah skala likert dan teknik analisis data yang digunakan adalah analisis regresi berganda dengan variabel moderating menggunakan software IBM SPSS 20.0.

\subsection{Uji Validitas dan Reliabilitas}

"Dalam penentuan layak atau tidaknya suatu item yang digunakan, dilakukan uji signifikansi koefisien korelasi pada taraf signifikansi 0,05, artinya suatu item dianggap valid jika berkorelasi signifikan terhadap skor totalnya" (Wiyono 2011: 112). Pengujiannya adalah sebagai berikut:

Jika $r$ hitung $\geq r$ tabel maka instrumen atau item-item pertanyaan berkorelasi signifikan terhadap skor total, maka dinyatakan valid.

Jika $r$ hitung < $r$ tabel maka instrumen atau item-item pertanyaan tidak berkorelasi signifikan terhadap skor total, maka dinyatakan tidak valid.

Sedangkan uji reliabilitas dengan taraf signifikansi 0,05 , artinya instrumen dinyatakan reliabel bila memiliki nilai alpha $>r$ kritis product moment.

\subsection{Uji Asumsi Klasik}

Uji asumsi klasik yang digunakan dalam penelitian ini adalah uji multikolinieritas, uji heteroskedastisitas, dan uji normalitas

\subsection{Uji Interaksi}

Uji interaksi atau moderated regression analysis (MRA) adalah aplikasi khusus regresi linear berganda dimana dalam persamaan regresinya mengandung unsur interaksi (perkalian dua atau lebih variabel independen).

Dalam penelitian ini rumus persamaannya sebagai berikut:

Prestasi Kerja $=\mathrm{a}+\mathrm{b} 1$ Kompensasi + b2 Motivasi + b3 Stres Kerja + b4 Kepemimpinan + b5 Kompensasi*Kepemimpinan + b6 Motivasi*Kepemimpinan + b7 Stres Kerja*Kepemimpinan $+\mathrm{e}$

Jika kepemimpinan merupakan variabel moderating antara kompensasi, motivasi dan stres kerja dengan prestasi kerja, maka koefisien b5, b6 dan b7 harus signifikan pada 0.05 atau 0.10 . 
INOBIS: Jurnal Inovasi Bisnis dan Manajemen Indonesia

Volume 1, Nomor 2, Maret 2018

Tegowati; Nenny Syahrenny; Wininatin Khamimah; Mega Arisia Dewi

\subsection{Uji Nilai Selisih Mutlak}

Dalam uji nilai selisih mutlak, akan menguji moderasi dari variabel independen. Uji nilai selisih mutlak dalam penelitian ini rumus persamaan regresinya sebagai berikut:

Prestasi Kerja $=\mathrm{a}+\mathrm{b} 1$ Kompensasi + b2 Motivasi + b3 Stres Kerja + b4 Kepemimpinan + b5 |Kompensasi - Kepemimpinan $\mid+$ b6 $\mid$ Motivasi - Kepemimpinan $\mid+$ b7 | Stres Kerja Kepemimpinan |

Sama seperti uji interaksi, dalam uji nilai selisih mutlak juga akan dianalisis uji koefisien determinasi, uji signifikansi simultan dan uji signifikansi parameter individual.

\section{Hasil Penelitian dan Pembahasan}

\subsection{Hasil Penelitian}

Hasil penelitian ini diperoleh dari penyebaran kuesioner kepada 116 guru di wilayah Wiyung Surabaya, namun yang kembali hanya 101 kuesioner. Sehingga untuk analisis hanya menggunakan data sebanyak 101 .

\subsection{Uji Validitas}

Dengan jumlah sampel (n) sebesar 101 dan alpha 0,05, maka besarnya $\mathrm{df}=(\mathrm{n}-2)$ adalah $101-2=0,1956$. Jika nilai $r$ hitung $\geq 0,1956$ maka instrumen dinyatakan valid. Berdasarkan perhitungan SPSS untuk validitas instrumen variabel kepemimpinan, kompensasi, motivasi, prestasi kerja dan stres kerja dapat diketahui bahwa semua indikator valid dan dapat digunakan untuk perhitungan selanjutnya.

Tabel 1.1: Validitas Instrumen Variabel

\begin{tabular}{lllll}
\hline \multicolumn{2}{l}{ Variabel dan Indikator } & & Nilai & Keterangan \\
\hline Kompensasi: & & & & \\
1. Gaji yang adil sesuai dengan & 0.836 & Valid \\
pekerjaan & & & 0.887 & Valid \\
2. Insentif yang sesuai dengan & 0.895 & Valid \\
pengorbanan & & & 0.660 & Valid \\
3. Tunjangan yang sesuai dengan & & \\
harapan & & & \\
4. Fasilitas yang memadai & & & \\
\hline $\begin{array}{l}\text { Motivasi: } \\
\text { 1. Termotivasi untuk bekerja }\end{array}$ & 0.830 & Valid \\
2. Berusaha menyelesaikan pekerjaan & 0.776 & Valid \\
3. Tetap bekerja dengan gigih meski & 0.735 & Valid \\
ada masalah & & & \\
\hline $\begin{array}{l}\text { Stres Kerja: } \\
\text { 1) Beban kerja yang berlebihan }\end{array}$ & 0.770 & Valid \\
2) Konflik dalam organisasi & 0.868 & Valid \\
3) Perbedaan pendapat dalam & 0.874 & Valid \\
pekerjaan & 0.713 & Valid \\
4) Masalah keluarga & & \\
\hline Kepemimpinan: & & \\
1. Mampu membuat perencanaan & 0.682 & Valid \\
\hline
\end{tabular}


INOBIS: Jurnal Inovasi Bisnis dan Manajemen Indonesia

Volume 1, Nomor 2, Maret 2018

Tegowati; Nenny Syahrenny; Wininatin Khamimah; Mega Arisia Dewi

\begin{tabular}{lll}
\hline 2. Mampu mengkoordinasi & 0.508 & Valid \\
3. Mampu menggerakan karyawan & 0.675 & Valid \\
4. Mampu berkomunikasi dengan & 0.700 & Valid \\
karyawan & 0.720 & Valid \\
5. Mampu mengawasi/mengontrol & 0.666 & Valid \\
6. Jujur/konsisten dalam memimpin & 0.709 & Valid \\
7. Tanggung jawab & 0.674 & Valid \\
8. Hubungan kerja dengan karyawan & 0.751 & Valid \\
9. Mau menerima pendapat karyawan & 0.627 & Valid \\
1. & & \\
\end{tabular}

10. Tidak pilih kasih

Prestasi Kerja:

1) Perencanaan Program Pembelajaran 0.700 Valid

2) Pelaksanaan Kegiatan Pembelajaran 0.749 Valid

3) Evaluasi/Penilaian Pembelajaran 0.708 Valid

Sumber: output SPSS

\subsection{Uji Reliabilitas}

Berdasarkan hasil analisis SPSS yang dilakukan, dapat diketahui pada tabel 1.1 untuk masing-masing variabel sudah reliabel karena nilai cronbach's alpha $>0,60$. Tabel 1.1 yang dimaksud adalah sebagai berikut:

Tabel 1.2 : Reliabilitas Instrumen Variabel

\begin{tabular}{lcc}
\hline Variabel & Cronbach's alpha & Keterangan \\
\hline Kepemimpinan & 0.757 & Reliabel \\
Kompensasi & 0.818 & Reliabel \\
Motivasi & 0.816 & Reliabel \\
Prestasi Kerja & 0.762 & Reliabel \\
Stres kerja & 0.816 & Reliabel \\
\hline
\end{tabular}

Sumber: output SPSS

\subsection{Uji Asumsi Klasik}

\subsubsection{Uji Asumsi Heteroskedastisitas}

Hasil pengujian pada gambar 1.2 menunjukkan scatterplot tidak membentuk pola tertentu serta titik-titik menyebar di atas dan di bawah angka 0 pada sumbu Y sehingga dapat disimpulkan bahwa model pada penelitian ini memenuhi syarat untuk menjadi model yang baik karena asumsi linieritas terpenuhi.

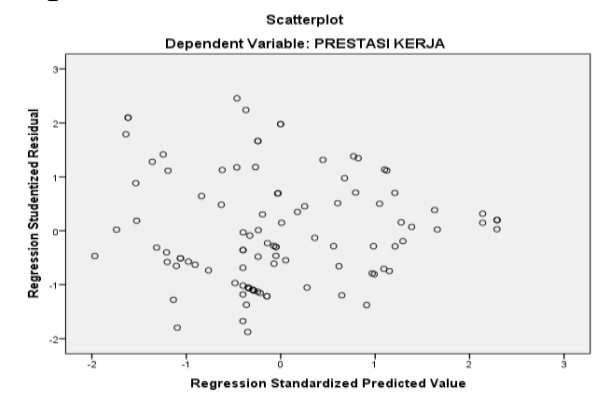

Gambar 1.2 : Uji Heteroskedastisitas Scatterplot Sumber: Output SPSS 
INOBIS: Jurnal Inovasi Bisnis dan Manajemen Indonesia

Volume 1, Nomor 2, Maret 2018

Tegowati; Nenny Syahrenny; Wininatin Khamimah; Mega Arisia Dewi

\subsubsection{Uji Asumsi Multikolinearitas}

Berdasarkan uji SPSS yang dilakukan menunjukkan bahwa nilai besaran korelasi antar variabel independen (tabel 1.2) masih di bawah 95\%, maka dapat dikatakan tidak terjadi multikolinieritas.

Tabel 1.2 : Coefficient Correlations

\begin{tabular}{llrrrr}
\hline \multicolumn{1}{c}{ Model } & Kepemimpinan & Stres kerja & Kompensasi & Motivasi \\
\hline Correlations & Kepemimpinan & 1.000 & -.156 & -.260 & -.372 \\
& Stres kerja & -.156 & 1.000 & .189 & .240 \\
& Kompensasi & -.260 & .189 & 1.000 & -.311 \\
\multirow{5}{*}{ Covariances } & Motivasi & -.372 & .240 & -.311 & 1.000 \\
& Kepemimpinan & .026 & -.006 & -.012 & -.035 \\
& Stres kerja & -.006 & .055 & .013 & .033 \\
& Kompensasi & -.012 & .013 & .089 & -.054 \\
& Motivasi & -.035 & .033 & -.054 & .344 \\
\hline
\end{tabular}

Sumber: Output SPSS

Hasil perhitungan nilai Tolerance memiliki nilai lebih dari 0.10 yang berarti tidak ada korelasi antar variabel independen yang nilainya lebih dari $95 \%$. Hasil perhitungan VIF juga menunjukkan tidak ada nilai lebih dari 10. Sehingga dapat disimpulkan bahwa tidak ada multikolinieritas antar variabel independen dalam model regresi yang digunakan. Adapun nilai Tolerance dan VIF yang dimaksud adalah sebagai berikut:

Tabel 1.3 : Nilai Tolerance dan VIF

\begin{tabular}{|c|c|c|}
\hline Model & \multicolumn{2}{|c|}{ Collinearity Statistics } \\
\hline (Constant) & Tolerance & VIF \\
\hline Stres kerja & & \\
\hline Motivasi & .863 & 1.159 \\
\hline Kompensasi & 619 & 1.615 \\
\hline Kepemimpinan & .680 & 1.470 \\
\hline & .703 & 1.422 \\
\hline
\end{tabular}

Sumber: Output SPSS

\subsubsection{Uji Asumsi Normalitas}

Dengan melihat tampilan grafik normal pada gambar plot 1.3 dapat disimpulkan bahwa model regresi memenuhi asumsi normalitas sebab data menyebar disekitar garis diagonal dan mengikuti arah garis diagonal.

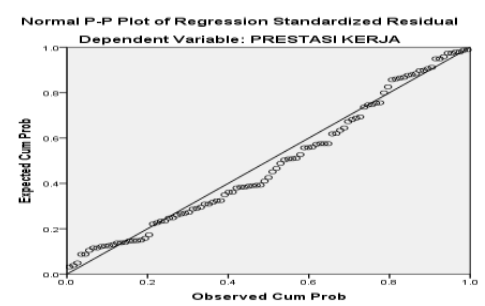

Gambar 1.3 : Normal P-P Plot

Sumber: Output SPSS 


\section{INOBIS: Jurnal Inovasi Bisnis dan Manajemen Indonesia \\ Volume 1, Nomor 2, Maret 2018 \\ Tegowati; Nenny Syahrenny; Wininatin Khamimah; Mega Arisia Dewi}

\subsection{Uji Interaksi}

Uji interaksi dilakukan analisis berdasarkan koefisien determinasi, uji signifikansi simultan, dan uji signifikansi parameter individual sebagai berikut:

\subsection{Uji Koefisien Determinasi}

Hasil uji interaksi pada output adjusted $\mathrm{R}^{2}$ pada tabel 1.4 menunjukkan bahwa model 1 memperoleh hasil sebesar 0.258 , hal ini menunjukkan bahwa 25,8\% variabel prestasi kerja dapat dijelaskan oleh variasi variabel independen kompensasi, kepemimpinan dan moderat1.

Sedangkan output adjusted $\mathrm{R}^{2}$ yang ke dua memperoleh hasil sebesar 0.334 , hal ini menunjukkan bahwa $33.4 \%$ variabel prestasi kerja dapat dijelaskan oleh variasi variabel independen motivasi, kepemimpinan dan moderat2. Kemudian output adjusted $\mathrm{R}^{2}$ yang ke tiga memperoleh hasil 0.191, yang menunjukkan bahwa $19.1 \%$ variabel prestasi kerja dapat dijelaskan oleh variasi variabel independen stres kerja, kepemimpinan dan moderat3. Adapun tabel 1.4 yang dimaksud adalah sebagai berikut:

Tabel 1.4 : Koefisien Determinasi

\begin{tabular}{llc}
\hline \multicolumn{2}{c}{ Model } & adjusted $\mathrm{R}^{2}$ \\
\hline 1. & $\begin{array}{l}\text { Pengaruh kompensasi terhadap prestasi kerja dengan } \\
\text { moderasi kepemimpinan. }\end{array}$ & 0.258 \\
2. $\begin{array}{l}\text { Pengaruh motivasi terhadap prestasi kerja guru dengan } \\
\text { moderasi kepemimpinan. }\end{array}$ & 0.334 \\
3. $\begin{array}{l}\text { Pengaruh stres kerja terhadap prestasi kerja guru dengan } \\
\text { moderasi kepemimpinan. }\end{array}$ & 0.191 \\
\hline
\end{tabular}

\subsection{Uji Signifikansi Simultan}

Uji Anova untuk model 1 menghasilkan nilai $\mathrm{F}$ hitung sebesar 12.591 dengan tingkat signifikansi 0.00. Nilai probabilitas dengan tingkat signifikansi kurang dari 0.05 ini menunjukkan bahwa kompensasi, kepemimpinan dan moderat1 secara bersama-sama berpengaruh terhadap prestasi kerja.

Sedangkan uji Anova atau F test model 2 menghasilkan nilai F hitung sebesar 17.690 dengan tingkat signifikansi 0.00 (jauh lebih kecil dari 0.05), maka dapat dikatakan bahwa motivasi, kepemimpinan dan moderat 2 secara bersama-sama berpengaruh terhadap prestasi kerja guru.

Kemudian $\mathrm{F}$ test model 3 menghasilkan nilai $\mathrm{F}$ hitung sebesar 8.863 dengan tingkat signifikansi 0.00 (jauh lebih kecil dari 0.05), maka dapat dikatakan bahwa stres kerja, kepemimpinan dan moderat3 secara bersama-sama berpengaruh terhadap prestasi kerja guru.

\subsection{Uji Nilai Selisih Mutlak}

Sama seperti uji interaksi, dalam uji nilai selisih mutlak juga akan dianalisis uji koefisien determinasi, uji signifikansi simultan dan uji signifikansi parameter individual.

\subsubsection{Uji Koefisien Determinasi}

Nilai Adjusted R2 untuk tiga analisis yang dilakukan menunjukkan nilai 0.255, 0.337, dan 0.197 . Hal ini menerangkan bahwa variabel prestasi kerja dapat dijelaskan oleh variabel 
INOBIS: Jurnal Inovasi Bisnis dan Manajemen Indonesia

Volume 1, Nomor 2, Maret 2018

Tegowati; Nenny Syahrenny; Wininatin Khamimah; Mega Arisia Dewi

Zkompensasi, Zkepemimpinan dan moderat1 sebesar 0,255 (untuk nilai Adjusted R2 pertama). Sedangkan nilai Adjusted R2 ke dua menerangkan bahwa variabel prestasi kerja dapat dijelaskan oleh variabel Zmotivasi, Zkepemimpinan dan moderat2 sebesar 0,337. Kemudian nilai Adjusted R2 yang ke tiga menerangkan bahwa variabel prestasi kerja dapat dijelaskan oleh variabel Zstres kerja, Zkepemimpinan dan moderat3 sebesar 0,197 dan sisanya dijelaskan oleh variabel lain di luar model yang diteliti.

\subsubsection{Uji Signifikansi Simultan}

Hasil uji F pertama menunjukkan nilai sebesar 18.087 dengan tingkat signifikansi 0.000 berarti bahwa variabel independen Zkompensasi dan moderat1 secara bersama-sama mempengaruhi prestasi kerja. Uji F kedua memberikan nilai sebesar 26.426 dengan tingkat signifikansi 0.000 yang berarti bahwa variabel independen Zmotivasi dan moderat2 secara bersama-sama mempengaruhi prestasi kerja. Sedangkan uji F ke tiga menunjukkan nilai sebesar 13.261 dengan tingkat signifikansi 0.000 . Hal ini menunjukkan bahwa variabel independen Zstres kerja dan moderat3 secara bersama-sama mempengaruhi prestasi kerja.

\subsubsection{Uji Signifikansi Parameter Individual}

Hasil output SPSS menunjukkan bahwa secara individu nilai variabel Zkompensasi sebesar 4.690 dengan signifikansi 0.000. Hal ini membuktikan bahwa variabel Zkompensasi berpengaruh terhadap prestasi kerja. Variabel moderating moderat1 menunjukkan nilai 0.005 (lebih kecil dari 0.05), yang menunjukkan bahwa variabel kepemimpinan merupakan variabel moderating.

Nilai Zmotivasi secara individu sebesar 5.073 dengan signifikansi 0.000 . Hal ini membuktikan bahwa variabel Zmotivasi berpengaruh terhadap prestasi kerja. Variabel moderating moderat2 menunjukkan nilai 0.053 (signifikan pada nilai 0.05), yang menunjukkan bahwa variabel kepemimpinan merupakan variabel moderating.

Sedangkan hasil output SPSS menunjukkan bahwa secara individu nilai variabel Zkompensasi sebesar 1.573 dengan signifikansi 0.118. Hal ini membuktikan bahwa secara parsial variabel Zstres kerja tidak berpengaruh terhadap prestasi kerja, namun secara simultan berpengaruh. Variabel moderating moderat3 menunjukkan nilai 0.000 (jauh lebih kecil dari 0.05), yang menunjukkan bahwa variabel kepemimpinan merupakan variabel moderating.

\subsection{Uji Hipotesis} berikut:

Kesimpulan uji hipotesis dalam penelitian ini dirangkum dalam tabel 1.5 sebagai

Tabel 1.5 : Kesimpulan Uji Hipotesis

\begin{tabular}{|c|c|c|c|c|c|}
\hline No. & Hipotesis & $\begin{array}{l}\text { Unstandardized } \\
\text { Coefficients }\end{array}$ & Sig. & Keterangan & Kesimpulan \\
\hline 1. & $\begin{array}{l}\text { Terdapat pengaruh kompensasi } \\
\text { terhadap prestasi kerja guru. }\end{array}$ & 4.690 & 0.000 & Signifikan & Terima H1 \\
\hline 2. & $\begin{array}{l}\text { Terdapat pengaruh motivasi } \\
\text { terhadap prestasi kerja. }\end{array}$ & 5.073 & 0.000 & Signifikan & Terima H2 \\
\hline 3. & $\begin{array}{l}\text { Terdapat pengaruh stres kerja } \\
\text { terhadap prestasi kerja guru. }\end{array}$ & 1.573 & 0.118 & $\begin{array}{c}\text { Tidak } \\
\text { Signifikan }\end{array}$ & Tolak H3 \\
\hline 4. & Terdapat pengaruh kompensasi & -2.072 & 0.005 & Signifikan & Terima H4 \\
\hline
\end{tabular}


INOBIS: Jurnal Inovasi Bisnis dan Manajemen Indonesia

Volume 1, Nomor 2, Maret 2018

Tegowati; Nenny Syahrenny; Wininatin Khamimah; Mega Arisia Dewi

terhadap prestasi kerja guru jika

dimoderasi oleh kepemimpinan.

Terdapat pengaruh motivasi

5. terhadap prestasi kerja guru jika

-1.394 $0.053 \quad$ Signifikan Terima H5

dimoderasi oleh kepemimpinan.

Terdapat pengaruh stres kerja

6. terhadap prestasi kerja guru jika

0.000

Signifikan

Terima H6

dimoderasi oleh kepemimpinan.

\subsection{Pembahasan}

Berdasarkan hasil pengujian terhadap hipotesis yang telah diajukan menunjukkan bahwa kompensasi dan motivasi berpengaruh secara positif dan signifikan terhadap prestasi kerja guru. Hal ini menunjukkan bahwa apabila kompensasi dan motivasi tinggi, maka prestasi kerja juga tinggi atau baik. Namun semakin menurun kompensasi dan motivasi, prestasi kerja juga akan semakin menurun. Hasil hipotesis 1 dan hipotesis 2 dalam penelitian ini mendukung penelitian yang dilakukan Paulus (2013) yang menunjukkan bahwa kompensasi dan motivasi kerja berpengaruh signifikan terhadap prestasi kerja.

Kemudian hasil analisis untuk hipotesis 3 dalam penelitian ini menunjukkan bahwa stres kerja tidak berpengaruh terhadap prestasi kerja guru. Hal ini tidak mendukung penelitian Nurmalasari (2015) yang menyatakan bahwa stres kerja mempunyai pengaruh terhadap prestasi kerja. Selanjutnya untuk hasil perhitungan hipotesis 4, hipotesis 5 dan hipotesis 6 menunjukkan bahwa kepemimpinan memoderasi kompensasi, motivasi dan stres kerja terhadap prestasi kerja guru.

Hal ini menunjukkan bahwa kepemimpinan yang bijaksana dapat memperkuat prestasi kerja guru. Kompensasi dan motivasi yang disertai perilaku pemimpin (dalam hal ini kepala sekolah) yang bijaksana dengan selalu memotivasi dan memberikan kompensasi yang sesuai dapat meningkat prestasi kerja guru.

\section{Simpulan dan Rekomendasi}

\subsection{Simpulan}

Berdasarkan pembahasan terhadap hipotesis yang diajukan dalam penelitian ini, maka kesimpulannya adalah sebagai berikut:

1. Kompensasi berpengaruh positif dan signifikan terhadap prestasi kerja. Hal ini ditunjukkan dari nilai Unstandardized Coefficients sebesar 4.690 dengan signifikansi 0.000. Dengan demikian, jika kompensasi semakin besar maka prestasi kerja juga semakin meningkat, dan sebaliknya jika semakin kecil kompensasi yang diperoleh maka prestasi kerja juga semakin rendah.

2. Motivasi kerja berpengaruh positif dan signifikan terhadap prestasi kerja. Hal ini ditunjukkan dari uji t pada nilai Unstandardized Coefficients sebesar 5.073 dengan signifikansi 0.000. Dengan demikian, jika motivasi semakin besar maka prestasi kerja juga semakin meningkat, dan sebaliknya jika motivasi kerja semakin kecil maka prestasi kerja juga semakin rendah.

3. Stres kerja tidak berpengaruh terhadap prestasi kerja guru. Hal ini ditunjukkan oleh uji t pada nilai Unstandardized Coefficients sebesar 1.573 dengan signifikansi 0.118. Dengan demikian, meskipun tingkat stres kerja guru yang tinggi maupun rendah tidak akan 
INOBIS: Jurnal Inovasi Bisnis dan Manajemen Indonesia

Volume 1, Nomor 2, Maret 2018

Tegowati; Nenny Syahrenny; Wininatin Khamimah; Mega Arisia Dewi

berpengaruh terhadap prestasi kerja. Artinya, prestasi kerja yang dicapai pada saat stres kerja tinggi akan sama atau tidak berbeda jauh saat stres kerja rendah.

4. Kompensasi berpengaruh terhadap prestasi kerja guru yang dimoderasi oleh kepemimpinan. Hal ini ditunjukkan oleh nilai Unstandardized Coefficients sebesar -2.072 (negatif) dan signifikansi 0.005 (lebih kecil dari 0.05). Dengan demikian, meskipun kompensasi rendah, prestasi kerja dapat meningkat jika kepemimpinan dapat dijalankan dengan efektif. Demikian pula sebaliknya, meskipun kompensasi tinggi tetapi kepemimpinan kurang efektif, maka prestasi kerja guru akan rendah.

5. Motivasi berpengaruh terhadap prestasi kerja guru yang dimoderasi oleh kepemimpinan. Hal ini ditunjukkan oleh uji t yaitu nilai -1.394 (negatif) dengan signifikansi 0.05 (signifikan pada nilai 0.05). Dengan demikian motivasi yang tinggi dan didukung dengan kepemimpinan yang baik dapat meningkatkan prestasi kerja guru. Sehingga meskipun motivasi kerjanya rendah, masih dapat menghasilkan prestasi kerja yang baik jika ada dukungan dari kepemimpinan yang baik. Begitu pula sebaliknya, motivasi yang tinggi dapat menurunkan prestasi kerja jika kepemimpinannya kurang efektif.

6. Stres kerja berpengaruh terhadap prestasi kerja guru yang dimoderasi oleh kepemimpinan. Hal ini ditunjukkan oleh nilai Unstandardized Coefficients sebesar -3.097 (negatif) dengan signifikansi 0.000 (jauh lebih kecil dari 0.05). Dengan demikian, stres kerja tinggi maupun rendah yang tadinya tidak berpengaruh terhadap prestasi kerja, dapat dioptimalkan dengan kepemimpinan yang efektif.

\subsection{Rekomendasi} adalah:

Berdasarkan kesimpulan penelitian ini, maka saran yang dapat diberikan oleh peneliti

a. Hendaknya pemimpin (dalam hal ini kepala sekolah) dapat berlaku bijaksana dalam menjalankan kepemimpinannya sebab perlakuan dari pemimpin yang dianggap bijaksana oleh para guru dapat memperkuat prestasi kerja guru.

b. Diketahui bahwa kompensasi dan motivasi berpengaruh terhadap prestasi kerja guru, untuk itu pemimpin diharapkan selalu memotivasi dan memberikan kompensasi yang sesuai supaya prestasi kerja guru dapat meningkat dan menciptakan citra yang baik untuk sekolah.

c. Hasil penelitian ini supaya dikaji lebih lanjut agar penelitian selanjutnya dapat menemukan penyebab tidak adanya pengaruh secara parsial stres kerja terhadap prestasi kerja. Kemudian perlu diteliti lebih lanjut stres kerja yang meliputi stres fisiologis, stres psikologis dan stres perilaku terhadap prestasi kerja.

\section{Daftar Pustaka}

Dewi, R. K. 2014. Analisis Pengaruh Stres Kerja Dan Kompensasi Terhadap Kinerja Karyawan (Studi Pada PT. Unggul Jaya Blora). Skripsi. Fakultas Ekonomika dan Bisnis Universitas Diponegoro, Semarang.

Hasibuan, M. 2012. Manajemen Sumber Daya Manusia. Edisi revisi: Bumi Aksara, Jakarta.

Hutagalung, C. 2016. Efek Moderator Gaya Kepemimpinan Pada Pengaruh Motivasi

Terhadap Kinerja Karyawan Kasus Pada Karyawan Tetap Dinas Perhubungan dan

Transportasi. Skripsi. Fakultas Ekonomi Universitas Sanata Dharma, Yogyakarta.

Kartono, K. 2010. Pemimpin dan Kepemimpinan. PT. Raja Grafindo Perkasa, Jakarta. 
INOBIS: Jurnal Inovasi Bisnis dan Manajemen Indonesia

Volume 1, Nomor 2, Maret 2018

Tegowati; Nenny Syahrenny; Wininatin Khamimah; Mega Arisia Dewi

Kely, T., T. Rahmi., dan Y. Y. Putra. 2015. Kontribusi Persepsi Pada Beban Kerja Dan Kecerdasan Emosi Terhadap Stres Kerja Guru SMP Yang Tersertifikasi. Jurnal Ilmiah Psikologi Terapan (JIPT). 3(1): 1-18.

Nurmalasari, A. 2015. Pengaruh Stress Kerja Terhadap Prestasi Kerja Pegawai Di Kecamatan Malinau Kota Kabupaten Malinau. Ejournal Pemerintahan Integratif, 1(3); 102-114.

Paulus, S. 2013. Motivasi Kerja, Kompensasi, Pelatihan dan Pengembangan, Karakteristik Pekerjaan Terhadap Prestasi Kerja Guru SMP di Kabupaten Kepulauan Talaud. Jurnal Emba. 1(4) : 582-595.

Rachmawati, T. dan Daryanto. 2013. Penilaian Kinerja Profesi Guru dan Angka Kreditnya. Gava Media. Yogyakarta.

Supardi. 2014. Kinerja Guru. Raja Grafindo Persada. Jakarta.

Suswati, E. dan I.A.Al. Ayyubi. 2008. Pengaruh Stress Kerja Terhadap Prestasi Kerja. Jurnal Manajemen Gajayana 5(2): 119-128.

Sutrisno, E. 2013. Manajemen Sumber Daya Manusia. Edisi Pertama. Kencana. Jakarta.

Widiartana, W. 2016. Pengaruh Gaya Kepemimpinan dan Motivasi Kerja Terhadap Prestasi Kerja Karyawan Pada UD. Sinar Abadi. Jurnal Program Studi Pendidikan Ekonomi. $6(1)$

Wijaya, T. dan F. Andreani. 2015. Pengaruh Motivasi dan Kompensasi Terhadap Kinerja Karyawan Pada PT Sinar Jaya Abadi Bersama. Jurnal AGORA 3(2): 37-45.

Zubaidi, M. H., 2016. Pengaruh Gaya Kepemimpinan Transformasional Terhadap Kinerja Karyawan Pada CV. Greenlane 99 ADV Kota Malang. Skripsi. Fakultas Ekonomi UIN Maulana Malik Ibrahim Malang, Malang.

http://referensi.data.kemdikbud.go.id/pd_index.php?level=3\&kode=056013\&id=5, diakses Juli 2017. 